\title{
CAN PRODUCERS APPLY A CAPACITY CUTTING STRATEGY TO INCREASE PRICES? THE CASE OF THE ENGLAND AND WALES ELECTRICITY MARKET
}

\section{Sherzod Tashpulatov Lubomír Lízal}
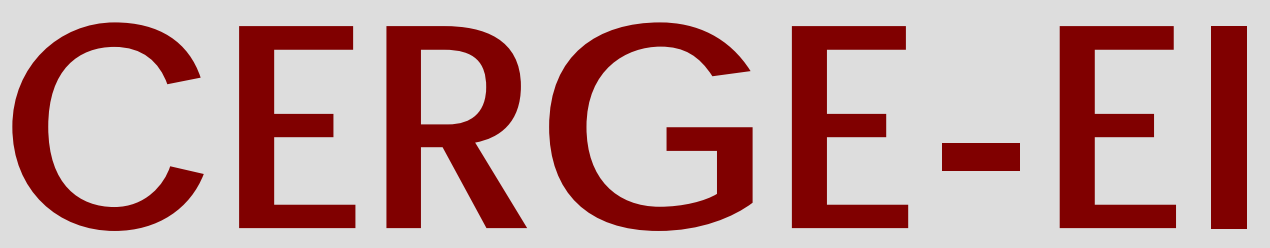

Charles University Centerfor Ec onomic Research and Graduate Education Academy of Sciences of the Czech Republic Ec onomic s Institute 


\section{Working Paper Series 465 (ISSN 1211-3298)}

\section{Can Producers Apply a Capacity Cutting Strategy to Increase Prices? The Case of the England and Wales Electricity Market}

Sherzod Tashpulatov

Lubomír Lízal

CERGE-EI

Prague, July 2012 
ISBN 978-80-7343-268-3 (Univerzita Karlova. Centrum pro ekonomický výzkum a doktorské studium)

ISBN 978-80-7344-260-6 (Národohospodářský ústav AV ČR, v.v.i.) 


\title{
Can Producers Apply a Capacity Cutting Strategy to Increase Prices? The Case of the England and Wales Electricity Market*
}

\author{
Sherzod Tashpulatov and Lubomír Lízal
}

\author{
CERGE-EI ${ }^{\dagger}$
}

\begin{abstract}
Promoting competition among electricity producers is primarily targeted at ensuring low electricity prices for consumers. Producers could, however, withhold part of production facilities (i.e., apply a capacity cutting strategy) and thereby push more expensive production facilities to satisfy demand for electricity. This behavior could eventually lead to a higher price determined through a uniform price auction.

In this paper, using the case of the England and Wales wholesale electricity market, we empirically examine whether producers can indeed apply a capacity cutting strategy. We analyze the bidding behavior of producers during high- and low-demand trading periods across trading days and find direct and indirect evidence for producers' successful manipulation of capacity bids targeted at increasing a wholesale electricity price. We also examine whether the regulatory reforms to improve competition were successful at mitigating the extent of strategic capacity manipulation.
\end{abstract}

\begin{abstract}
Abstrakt
Podpora konkurence mezi výrobci elektřiny má primárně za cíl zajistit nízké spotřebitelské ceny elektřiny. Výrobci by však mohli nevyužít část produkčních kapacit (tj., aplikovat strategii snižování kapacity) a tím prosadit dražší produkční jednotky k uspokojení poptávky po elektřině. Toto chování by v konečném důsledku mohlo vést k vyšším cenám určeným uniformní cenovou aukcí.

V tomto článku využíváme př́klad anglického a velšského velkoobchodního trhu s elektřinou a empiricky zkoumáme, zda producenti mohou skutečně aplikovat strategii snižování kapacity. Analyzujeme nabídkové chování producentů během vysoko a nízko poptávkových obchodních období napříč obchodovacími dny a nacházíme přímé a nepřímé důkazy toho, že výrobci úspěšně manipulují kapacitní nabídkou s cílem zvýšit velkoobchodní cenu elektřiny. Rovněž hodnotíme, zda regulační reformy s cílem zlepšit konkurenci byly úspěšné při zmírnění rozsahu takové strategické manipulace.
\end{abstract}

Keywords: capacity bids, electricity prices, uniform price auction, regulation JEL Classification: D22, D44, L50, L94

*We thank Peter Katuščák and Jan Kmenta for detailed comments. We also thank Laura Straková for English editing. This research was supported by a grant from the CERGE-EI Foundation under a program of the Global Development Network. All opinions expressed are those of the authors and have not been endorsed by CERGE-EI or the GDN. The usual disclaimer applies.

${ }^{\dagger}$ A joint workplace of the Center for Economic Research and Graduate Education, Charles University, and the Economics Institute of the Academy of Sciences of the Czech Republic Address: CERGE-EI, P.O. Box 882, Politickych veznu 7, Prague 111 21, Czech Republic E-mail: stashpul@cerge-ei.cz, lubomir.lizal@cerge-ei.cz 


\section{Introduction}

Prices of goods and services of general interest play a key role in determining the welfare of a society. Electricity, which usually accounts for the lion's share of energy consumption, is among those kinds of goods. Understanding the sources and reasons of high electricity prices therefore becomes an important task.

There are several means by which producers could set high prices. The most common is through an exercise of market power, whereby producers charge prices significantly exceeding their marginal production costs. For the case of the England and Wales electricity market, this type of noncompetitive behavior of electricity producers has been studied by, for example, Green and Newbery (1992), Von der Fehr and Harbord (1993), Wolfram (1998), Crawford et al. (2007), and Sweeting (2007).

Another means by which producers could set high prices is through the creation of an artificial deficit. Given a sufficiently high level of demand, this strategy could be successful at increasing prices. In general, cases of creating an artificial deficit in order to increase prices have been observed in various contexts. One historical example is burning coffee beans in Brazil, which was successful at increasing Brazilian coffee prices in New York by more than 40\% (Brazil: Destroy! Destroy!, June 6, 1932). Late in 2008, the E.ON AG electricity producer was investigated by the European Commission for abusing its dominant position to withhold available production facilities in the German electricity market with a view to raising electricity prices to the detriment of consumers (European Commission, February 13, 2009). Another recent example is the artificial creation of a deficit of diesel fuel by oil companies in Russia, which resulted in excessively high prices. The artificial deficit in this case was created by shutting down plants for maintenance reasons (Ceni na solyarku: polniy absurd i naglost - Prices of Diesel Fuel: Complete Absurdity and Impudence, April 14, 2011).

Fridolfsson and Tangerås (2009), using the case of the Nordic wholesale electricity 
market, suggest that producers may have an incentive to withhold base-load nuclear plants to increase output prices without driving a wedge between output prices and marginal production costs. The authors therefore conclude that strategic withholding when demand is relatively high could be another means of increasing prices.

In our research, we define capacity cutting as a reduction of the amount of declared available capacity of a production unit in the half-hourly day-ahead auction. An extreme case of applying a capacity cutting strategy is declaring a production unit as unavailable for electricity production, which may not be inexpensive in terms of the associated startup costs.

Exploitation of a capacity cutting strategy undermines the allocative efficiency of production resources. In other words, capacity cutting can introduce distortions to the least-cost production schedules intended to serve demand at lower prices. As a consequence, it may become necessary to operate more expensive production facilities to satisfy demand for electricity at higher prices, whose burden is then eventually transferred to consumers.

Comparing the two means, manipulation of price bids and capacity bids, CastroRodriguez et al. (2009) conclude that because a regulatory authority can relatively easily monitor the short-run competition, capacity bids could be regarded as an alternative instrument through which producers may affect prices.

In this research, using the case of the England and Wales wholesale electricity market, we examine if producers could indeed apply a capacity cutting strategy to increase electricity prices. For this purpose we analyze the bidding behavior of producers between high- and low-demand trading periods (usually evening and afternoon periods). The intra-day analysis of the bidding behavior during different trading days is advantageous for the day-ahead auction, because producers are asked to submit capacity bids in advance for each half-hourly trading period of the next trading day. In contrast, an 
inter-day analysis (for example, based on the comparison of high-demand periods over different trading days) may not be conclusive, because capacity could have been reduced due to brief maintenance, fuel reload, etc. We also quantitatively assess whether the regulatory reforms during the liberalization process were successful at decreasing the extent to which capacity bids could be manipulated.

In the following sections we first describe the market rules and institutional background. We then review the related literature. In the empirical methodology we describe the regression model, econometric assumptions, and estimation strategy. Finally we present our estimation results and discussion.

\section{Electricity Auction and Regulation}

In this section we first describe the operation of the wholesale electricity market in England and Wales. In particular, using a hypothetical example, we explain the role of producers and the market operator (i.e., the auctioneer). We then proceed to the description of a capacity cutting strategy aimed at increasing the wholesale price. Finally, we describe the reforms introduced by the regulatory authority, the Office of Electricity Regulation (OFFER), which were targeted at improving competition and ensuring lower electricity prices.

At the start of liberalization, a wholesale market for electricity trading was created. Trading was organized through a half-hourly uniform price auction, where electricity producers are asked to submit half-hourly capacity bids and daily bids for all production units. Half-hourly price bids for every production unit are calculated based on daily bids and half-hourly declared capacity bids. Daily bids include incremental price bids, elbow points, start-up and no-load costs. These rules are common knowledge and described in detail in the Electricity Pool (1990), which is a technical summary used by the market 
operator (the National Grid Company, NGC). A more intuitive description of trading rules, including the GOAL algorithm, is also presented in Sweeting (2007).

The market operator orders all production units based on price bids to construct a half-hourly production schedule. The market operator also prepares demand forecasts, where the forecasting methodology is common knowledge (see Wolak, 2000; Wolak and Patrick, 2001). The forecasting methodology is also independent of producers' bidding behavior (see Green, 2006). The production unit whose price bid in the production schedule intersects price-inelastic forecasted demand is called the marginal production unit. Its price bid is called the System Marginal Price (SMP) and represents the wholesale price for electricity production during a given half-hourly trading period. This is the uniform auction price paid the same for producers' production units needed to satisfy demand for electricity.

In Figure 2.1, we schematically illustrate how the electricity market would have operated in a given half-hourly trading period.

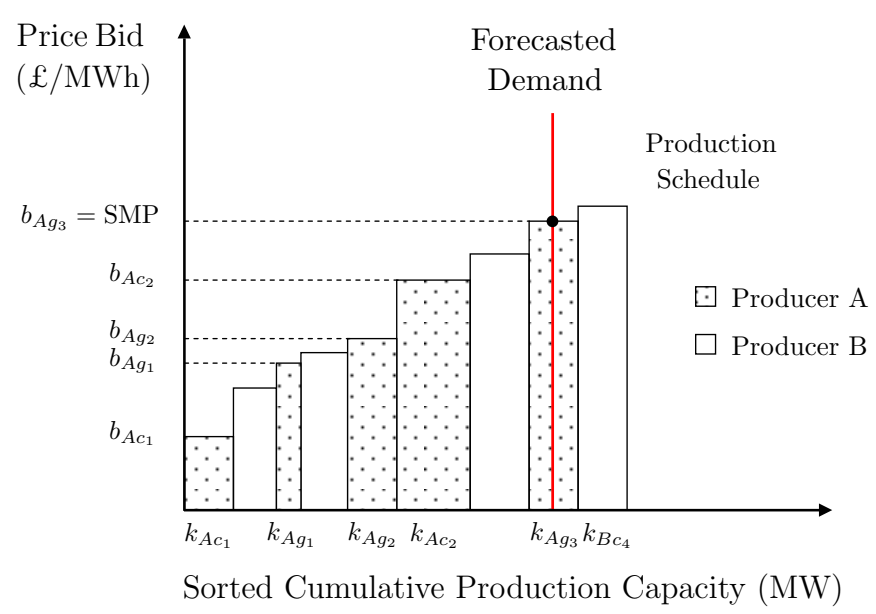

Source: Authors' illustration.

Figure 2.1: Determination of the System Marginal Price (SMP)

Let $b_{A c_{1}}$ denote the price bid of electricity producer A's first coal production unit for which the submitted (declared) production capacity is $k_{A c_{1}}$. For the sake of simplicity, 
it is assumed that electricity producer A has two coal and three gas types of production unit. Price bids of all production units are ordered as would have been done by the market operator to create a half-hourly production schedule. The vertical line in the graph is forecasted demand. The intersection of the constructed production schedule and price-inelastic forecasted demand determines the SMP, the wholesale electricity price. In this hypothetical example, it is electricity producer A's third gas production unit whose price bid determines the SMP.

Submitted half-hourly capacity bids and price bids for individual production units represent private knowledge for each producer that owns those production units. This is a feature of a sealed-bid uniform price auction, where the bids of one producer are unknown to the other producers.

Assuming no changes in demand during the trading periods $\mathrm{L}$ and $\mathrm{H}$, in the hypothetical example presented in Figure 2.2 we illustrate how a producer could have removed or decreased production capacity (i.e., apply a capacity cutting strategy) in order to increase the wholesale price, which is paid the same to all production units needed to satisfy demand for electricity, and thereby, to enjoy higher profits.

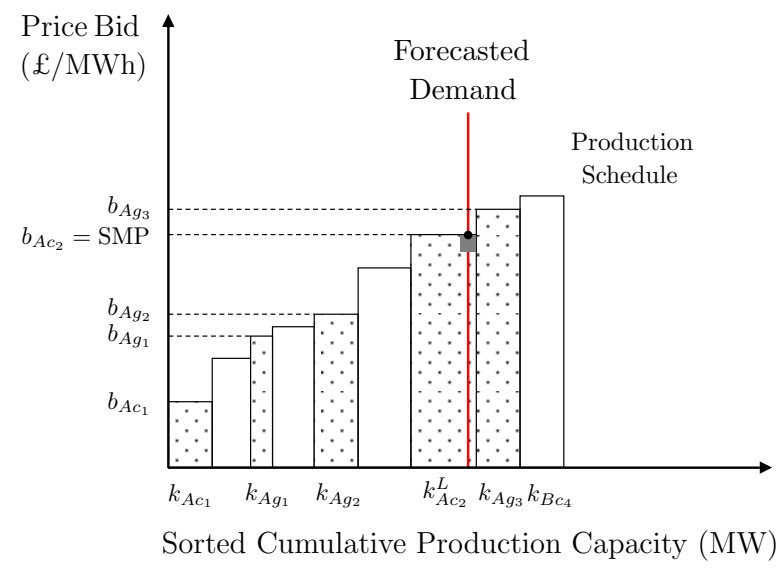

(a) No Capacity Cutting

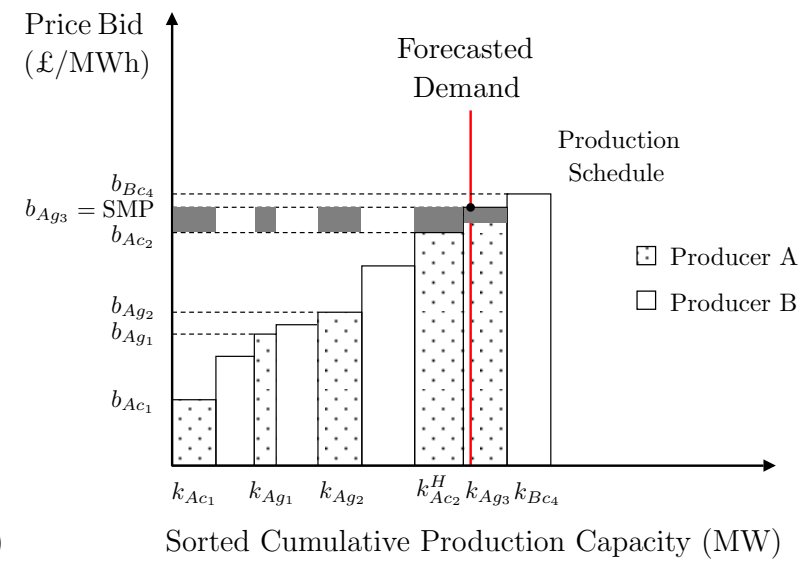

(b) Capacity Cutting

Source: Authors' illustration.

Figure 2.2: Capacity Strategy when Demand is Constant: No Cutting vs. Cutting 
In this example, we assume that producer A has decided to decrease the capacity of its second coal production unit. ${ }^{1}$ The associated loss is depicted by a shaded area in Figure 2.3(a) and the associated gain is depicted by a shaded area in Figure 2.3(b). From the presented example we see that applying capacity cutting may indeed be profitable and could even serve as a positive externality to competitors, which all eventually decrease consumers' welfare.

In Figure 2.3, we consider the same example as in Figure 2.2, but for the case in which demand increases. Specifically, we illustrate how a producer could apply a capacity cutting strategy during high-demand trading periods compared to low-demand trading periods in order to increase the wholesale price and achieve higher profits.

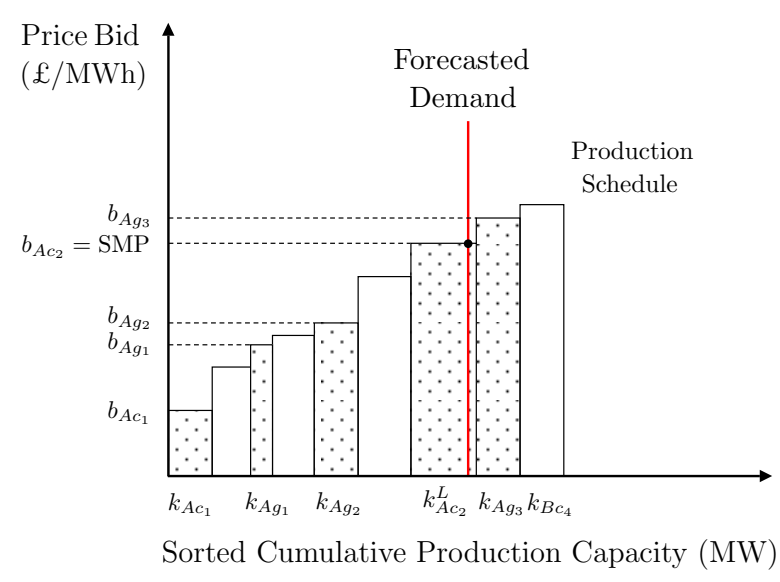

(a) Low-Demand Trading Period

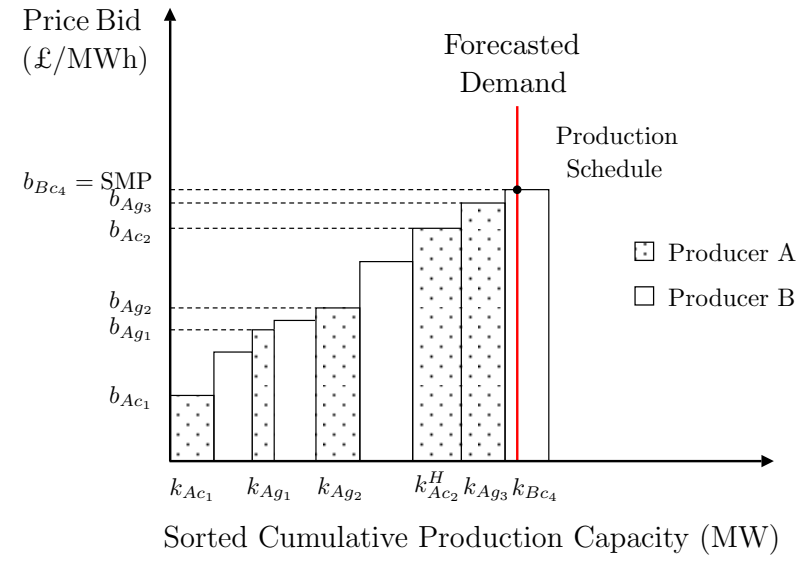

(b) High-Demand Trading Period

Source: Authors' illustration.

Figure 2.3: Capacity Strategy when Demand Increases: No Cutting vs. Cutting

In this example, we again assume that producer A has decided to decrease the capacity of its second coal production unit when submitting capacity bids for a high-demand trading period. As illustrated in Figure 2.3(b), a total increase in the wholesale price is due to two factors: an increase in demand and an application of capacity cutting.

The regulatory authority, the OFFER, noticed cases of excessively high electricity

\footnotetext{
${ }^{1}$ Withholding a whole production unit can be interpreted as a special case of a capacity cutting strategy.
} 
prices, which were attributed to the possible noncompetitive bidding behavior of the incumbent electricity producers (National Power and PowerGen). In order to decrease the influence of the incumbent producers on the wholesale electricity market, the regulatory authority introduced several reforms in the Electricity Supply Industry (ESI) in Great Britain. The time of the introduced institutional changes and regulatory reforms define different regime periods, which are summarized in Figure 2.4.

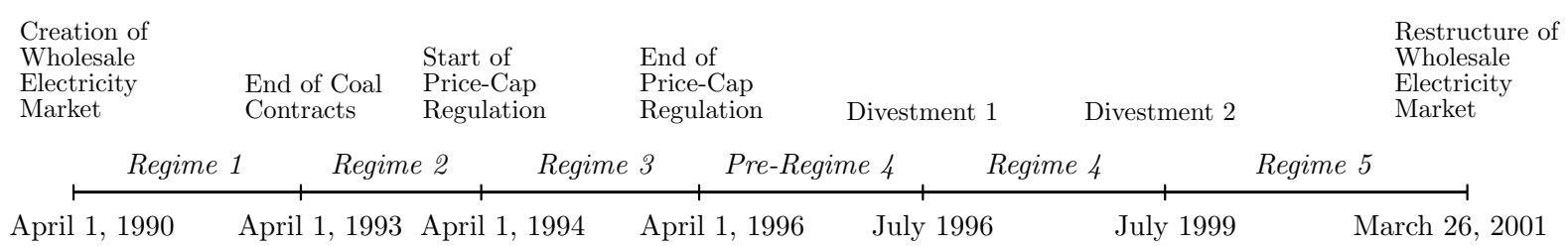

Sources: Department of Trade and Industry (1997-2002), National Grid Company (1994-2001), Newbery (1999), Robinson and Baniak (2002), Wolfram (1999); Authors' illustration.

Figure 2.4: Institutional Changes and Regulatory Reforms in the ESI in Great Britain during 1990-2001

At the time of the creation of the wholesale electricity market, coal and other contracts were introduced by the government, which then expired in 1993. Later, the regulatory authority introduced price-cap regulation and divestment series. The price-cap regulation during 1994-1996 was a temporary measure designed to control the annual average prices set by the incumbent electricity producers. In order to decrease market concentration and improve competition, the incumbent electricity producers were asked to divest part of their production facilities, which took place in 1996 and 1999. In March 2001, the wholesale electricity market was restructured to introduce bilateral trading arrangements.

When defining regime periods we consider the exact dates when the reforms were introduced. This approach better reflects the nature of the divestment series introduced by the regulatory authority. For example, the introduction of the first series of divestments for PowerGen led to the transfer of all medium coal production facilities to Eastern Group, which was later renamed TXU (National Grid Company, 1994-2001). A separate analysis of the bidding behavior of PowerGen with respect to medium coal production 
facilities several days or weeks before the actual divestment took place may not be statistically reliable due to a small number of observations. For Eastern Group, it would not be possible because Eastern Group did not have coal production facilities before and therefore could not participate in the auction by submitting bids for coal production units. Hence, we assume that the structural breaks are exogenously given by the dates when the reforms were introduced. It is also worth mentioning that the structural changes introduced through the two divestment series differ, because the first series of divestments included the lease and the second series of divestments included the sale of production facilities (National Grid Company, 1994-2001). Hence, the effect of the two divestment series, generally, need not be the same.

Table 2.1 describes the distribution of shares of production capacity and price setting among electricity producers between the financial years 1995/1996 and 1999/2000. To the original table reproduced from Bishop and McSorley (2001) we have added a measure of the Herfindahl-Hirschmann Index (HHI) computed as a sum of squared shares. The calculations show that thanks to the divestment series and new entry the concentration measure decreased by almost twofold.

Similarly to Borenstein et al. (2002) we restrict our analysis to electricity producers located in England and Wales. The excluded exporters, EdF and Scottish Interconnector, were not suspected of abusing market power or manipulating capacity bids.

The measures designed to promote competition during the liberalization were more extensive in Great Britain compared to Germany, France, Italy, or Sweden (Bergman et al., 1998). In particular, Paul Joskow characterized the privatization, restructuring, market design, and regulatory reforms pursued in the liberalization process of the electricity industry in England and Wales as the international gold standard for energy market liberalization (Joskow, 2009). In this respect, Great Britain, with the longest experience of a liberalization process, can also serve as an important source of lessons. 
Table 2.1: Structural Impact of National Power and PowerGen Divestments

\begin{tabular}{rlrrrr}
\hline & & \multicolumn{2}{c}{ Share of Capacity } & \multicolumn{2}{c}{ Share of Price Setting } \\
& & $1995 / 1996$ & $1999 / 2000$ & $1995 / 1996$ & $1999 / 2000$ \\
\hline 1 & National Power & 33.7 & 13.0 & 44.8 & 14.6 \\
2 & PowerGen & 28.1 & 16.5 & 31.8 & 16.8 \\
3 & BNFL Magnox & 5.8 & 5.4 & 0.0 & 0.0 \\
4 & EdF & 3.3 & 3.3 & 0.7 & 10.7 \\
5 & Scottish Interconnector & 2.3 & 2.2 & 1.7 & 0.4 \\
6 & TXU & 1.6 & 9.2 & 7.3 & 11.8 \\
7 & Edison & 3.8 & 8.9 & 0.0 & 21.1 \\
8 & British Energy & 12.0 & 14.8 & 0.0 & 19.9 \\
9 & AES & 0.5 & 7.6 & 0.5 & 0.4 \\
10 & Combined cycle gas turbines & 7.8 & 17.2 & 0.0 & 0.0 \\
11 & Others & 1.3 & 2.0 & 0.33 & 0.16 \\
\hline
\end{tabular}

Source: Reproduced from Bishop and McSorley (2001).

Note: $\mathrm{HHI}=$ Herfindahl-Hirschmann Index (sum of squared shares: monopoly $=1$ ).

\section{Literature Review}

Le Coq (2002) and Crampes and Creti (2006) analyze a two-stage duopoly game, where producers first decide on capacity bids and then compete in a uniform price auction. The authors find that a uniform price auction creates incentives for strategic capacity cutting when demand is known. Sanin (2006) generalizes this result for the case of stochastic demand.

Joskow and Kohn (2002) study the California spot electricity market during the California electricity crisis that cost $\$ 40$ billion in added energy costs (Weare, 2003) and find that even after accounting for low levels of imports, high demand for electricity, and high prices of $N O_{x}$ emissions permits, there are still large deviations of wholesale market prices from the competitive benchmark prices, i.e., the marginal cost of supplying additional electricity at the associated market clearing quantities. The authors find that capacity cutting, which is observed from substantial gaps between maximal and submitted capacity bids at peak hours, could explain the remaining deviations from the 
competitive benchmark prices. The observation of gaps between maximal and submitted capacity bids during peak hours has been important for the development of our regression analysis, where we compare capacity bids during low- and peak-demand trading periods across different trading days for the case of the electricity market in England and Wales.

The application of competitive benchmark prices to analyze whether an electricity market, as a whole, is setting competitive prices has an advantage of being less vulnerable to the arguments of coincidence and bad luck. This approach also allows estimating the scope and severity of departures from competitive bidding over time (see, for example, Borenstein et al., 2002).

Sweeting (2007) similarly applies the methodology of competitive benchmark prices to analyze the development of market power in the England and Wales electricity market. The author finds that electricity producers were exercising increased market power in the late 1990s. This finding, as the author indicates, is however in contradiction with oligopoly models, which, given that during this period market concentration was falling, would have predicted a reduction in market power.

Sweeting (2007) also finds that from the beginning of 1997 the National Power and PowerGen incumbent electricity producers could have increased their profits by submitting lower price bids and increasing output. These findings are explained as tacit collusion. The latter finding, however, could also be related to capacity cutting or expanding, which we empirically analyze in this research.

Wolak and Patrick (2001) and Green (2004) empirically study strategic capacity cutting in the same electricity market. Wolak and Patrick (2001) find that capacity bids are a more "high-powered" instrument than price bids to manipulate market rules. In particular, by analyzing the pattern of submitted half-hourly capacity bids, the authors conclude that the incumbent producers were strategically withholding capacity to increase wholesale prices. Wolak and Patrick (2001), however, do not consider any model and the 
conclusions are mainly drawn from time series observations and probability distributions.

In contrast, in our research we use a regression model and consider the period during the late 1990s. This period also includes several new entrants like the TXU and AES producers. Our approach to consider demand increases within different trading days as producers' possible incentive to manipulate half-hourly capacity bids is, in general, consistent with observations in Wolak and Patrick (2001) and Joskow and Kohn (2002).

Green (2004) finds that withholding high-cost capacity, which probably will not be scheduled to produce electricity, has no impact on prices. However, withholding capacity leads to an increase in the probability that demand will exceed supply (known as the loss of load probability (LOLP)) that will ultimately increase capacity payments. Historically, PowerGen successfully applied this strategy during the summer and early fall of 1991. The producer had to stop this practice in response to criticism by the regulatory authority.

Almost a decade later, in June 2000, Edison similarly withdrew a large coal production unit of 480 MW capacity from the Fiddlers Ferry plant, which was again investigated by the regulatory authority. The withdrawn production capacity presents about $1 \%$ of total production capacity operated during peak-demand periods in England and Wales (National Grid Company, 1994-2001). In July, the producer agreed to return the plant to the system and the regulatory authority did not take any action (OFGEM, July 12, 2000a). The strategic withholding was calculated to cause a $10 \%$ increase in wholesale prices during June-July, which approximately corresponded to a total increase of $£ 100$ million (OFGEM, December 11, 2000b).

By analyzing monthly averages, Green (2004) shows that the increased benefits (i.e., higher capacity payments, which are computed using data on the LOLP and SMP) from withholding capacity usually did not exceed the costs of keeping plants open. Based on this finding the author concludes that the evidence for large-scale capacity withholding is weak. 


\section{Empirical Methodology}

In general, when demand increases, producers could cut or expand production capacity. We use a regression analysis to examine these strategies. Specifically, we consider the following two regression equations:

$$
\begin{aligned}
& s_{i j t}^{H}-s_{i j t}^{L}=\alpha_{0 i j}+\alpha_{1 i j} \cdot \text { growth in demand }_{t}+\varepsilon_{i j t} \text {, for the cutting sample } \\
& s_{i j t}^{H}-s_{i j t}^{L}=\beta_{0 i j}+\beta_{1 i j} \cdot \text { growth in demand }_{t}+\epsilon_{i j t} \text {, for the expanding sample. }
\end{aligned}
$$

Subscripts $i$ and $j$ denote producer and input type, respectively. The dependent variable is defined as the difference between shares of production capacities made available during the highest-demand and a lower-demand trading periods (at producer and input type levels). Negative values of the dependent variable correspond to capacity cutting and positive values to capacity expanding cases. The explanatory variable, growth in demand, is defined as a relative increase in forecasted demand during the highest-demand trading period compared to a lower-demand trading period.

We consider five-hour differences between the highest-demand and lower-demand trading periods. The results are generally similar to those which are based on alternative choices of a lower-demand trading period as a comparison benchmark. More importantly, because noncompetitive bidding behavior could usually be observed during high-demand trading periods, similarly to Joskow and Kohn (2002) and Crawford et al. (2007), we compare the bidding behavior of electricity producers in relation to the highest-demand (i.e., peak-demand) trading periods.

The disturbance terms in the regression models are assumed orthogonal to the explanatory variable. The exogeneity assumption of the explanatory variable is in line with the fact that the forecasting methodology the market operator applies is, firstly, common knowledge (see, for example, Wolak, 2000; Wolak and Patrick, 2001) and, secondly, 
independent of producers' bidding behavior (Green, 2006).

The intercept and slope parameters are assumed to be producer and input type specific. $^{2}$ Because the model variables are defined in relative terms, we can interpret the slope parameter in terms of elasticity. In particular, the slope parameter measures the extent to cut or expand capacity when demand increases by $1 \%$. The intuition that an increase in demand affects the extent of capacity cutting or expanding is testable. In particular, if the capacity cutting hypothesis holds, then we should obtain statistical evidence that an increase in demand induces a decrease in capacity made available for electricity production. Alternatively, if the capacity expanding hypothesis holds, then we should obtain statistical evidence that an increase in demand induces an increase in capacity made available for electricity production.

Estimating the cutting and expanding regression equations separately may be subject to sample selection bias. The sample selection problem arises in our research because we have selected two samples based on the cutting and expanding cases. In order to correct for the sample selection problem, we use Heckman's two-step procedure developed in Heckman (1979).

In the first step we estimate the selection equation using the probit model. In the probit model, for explanatory variables, which may explain the decision for capacity cutting or expanding, we consider demand and wholesale price (i.e., the SMP) increases. The motivation for including wholesale price increases stems from the analysis of profit accounting during high- and low-demand trading periods. The details are presented in Appendix A.

The fitted values from the probit model are used to calculate $\lambda_{i j t}$, the inverse of Mill's

\footnotetext{
${ }^{2} \mathrm{~A}$ producer can, in general, use different inputs (e.g., coal, gas, etc.) to produce electricity. Therefore we distinguish production capacities that use different inputs. Moreover, coal input can be used in large-, medium-, and small-sized plants. Because the efficiency rate of production capacity in these plants is different, we also distinguish large coal, medium coal, and small coal types of production capacity. These types of production capacity are usually located in different parts of the aggregate supply schedule. For this reason, we consider producer and capacity type specific parameters.
} 
ratio, which is a decreasing function of the probability that an observation is selected into the sample. The calculated $\hat{\lambda}_{i j t}$ is then used in the second step as an additional explanatory variable to estimate the amount equation.

Below we formally summarize the estimation procedure:

$$
\begin{gathered}
\mathrm{P}(\text { Decision }=1 \mid \mathbf{x})=\Phi\left(\delta_{0 i j}+\delta_{1 i j} \cdot \text { growth in demand }+\delta_{2 i j} \cdot \text { growth in } \mathrm{SMP}_{t}\right) \\
s_{i j t}^{H}-s_{i j t}^{L}=\alpha_{0 i j}+\alpha_{1 i j} \cdot \text { growth in demand } t+\gamma_{C} \cdot \hat{\lambda}_{i j t}^{C}+\varepsilon_{i j t}
\end{gathered}
$$

where the second equation is estimated for the cutting sample, which corresponds to Decision $=1$. $\hat{\lambda}_{i j t}^{C}$ is calculated as a ratio of $\hat{\phi}(\cdot)$ and $\hat{\Phi}(\cdot)$. Only observations from the cutting sample are used in estimating the second equation, which is called the amount equation. ${ }^{3}$

This Heckman's two-step procedure is also described in detail in Kmenta (2004). This procedure allows estimating the cutting and expanding regression equations free of sample selection bias.

Therefore, the regression equations describing capacity cutting and expanding behaviors are modified in the following way:

$s_{i j t}^{H}-s_{i j t}^{L}=\alpha_{0 i j}+\alpha_{1 i j} \cdot$ growth in demand $_{t}+\gamma_{C} \cdot \hat{\lambda}_{i j t}^{C}+\varepsilon_{i j t}$, for the cutting sample $s_{i j t}^{H}-s_{i j t}^{L}=\beta_{0 i j}+\beta_{1 i j} \cdot$ growth in demand $_{t}+\gamma_{E} \cdot \hat{\lambda}_{i j t}^{E}+\epsilon_{i j t}$, for the expanding sample

If $\hat{\gamma}_{C}$ and $\hat{\gamma}_{E}$ are found statistically significant, then we can conclude that there would have been a sample selection bias, had we not included $\hat{\lambda}_{i j t}^{C}$ and $\hat{\lambda}_{i j t}^{E}$ in the amount equations.

For the regulation analysis, we assume that producer and input type specific intercept

\footnotetext{
${ }^{3}$ In order to apply Heckman's two-step procedure for the expanding sample, we similarly consider Decision $=1$ for the expanding case.
} 
and slope parameters need not be the same during different regime periods discussed in Section 2. This approach allows us to draw conclusions regarding the effectiveness of regulatory reforms in disciplining the bidding behavior of electricity producers.

During later regime periods, a decrease in the incentive to make more capacity available when demand increases is interpreted as an indication of indirect capacity cutting. We test for the presence of indirect capacity cutting by verifying if a slope coefficient in front of an interaction term between a regime dummy variable and demand in the expanding amount equation is negative and statistically significant.

\section{Data}

The available data consist of two data sets covering the period January 1, 1995 - September 30, 2000. The first data set contains half-hourly market data for each trading period and includes observations on the System Marginal Price (SMP) and forecasted demand for electricity. A summary of these data with the associated measurement units is provided in Table B.1. Using data on the forecasted demand, we compute demand increases as a relative change in the forecasted demand during the highest-demand trading period compared to a lower-demand trading period.

The second data set contains data on half-hourly capacity bids (i.e., declared availability) and price bids for each trading period, which also includes the identity of an electricity producer, plant, production unit, and input type. A summary of these data, with the associated measurement units, is provided in Table B.2.

In order to exclude the ambiguity that some production capacity is not made available to the market due to, for example, maintenance and other technical reasons, we consider capacity bids on a daily basis. More precisely, for each trading period we first compute the shares of production capacities of various input types for all producers with respect 
to an individual producer's maximal production capacity made available for each input type during a given trading day. Producers' shares of production capacities of each input type in low- and high-demand trading periods during a given trading day are then used in defining the dependent (explained) variable in the regression analysis.

Detailed information and acknowledgments to people and organizations contacted with in the process of collecting data and materials will be listed at a later stage of the dissertation research.

\section{Results and Discussion}

The discussion of results is divided into two parts. First, we discuss the results of the probit selection equation in which Decision $=1$ corresponds to the cutting case. The estimation of this selection equation is necessary to calculate $\hat{\lambda}_{i j t}^{C}$ for the cutting amount equation. Changing Decision $=1$ to the expanding case, which is needed to calculate $\hat{\lambda}_{i j t}^{E}$ for the expanding amount equation, does not change our conclusions and therefore its discussion is omitted. We then proceed to the discussion of results for the amount equations describing capacity cutting and expanding behaviors of producers.

\subsection{Selection Equation}

The analysis includes cases in which capacity cutting and expanding are observed. They represent 11,812 and 17,624 observations, respectively. Decision $=1$ corresponds to the cutting case. Below in Table 6.1 we present our estimation results for the probit selection equation.

The results reveal that the incumbent producers, National Power and PowerGen, face a trade-off in deciding to apply capacity cutting when demand and wholesale price (i.e., the SMP) are expected to increase during the highest-demand trading periods. In 
Table 6.1: Probit Selection Equation

$\mathrm{P}($ Decision $=1 \mid \mathbf{x})=\Phi\left(\delta_{0 i j}+\delta_{1 i j} \cdot\right.$ growth in demand $t+\delta_{2 i j} \cdot$ growth in $\left.\mathrm{SMP}_{t}\right)$

\begin{tabular}{|c|c|c|c|c|c|c|c|}
\hline \multirow[t]{2}{*}{ Dep. } & \multirow[t]{2}{*}{ Var.: Decision } & \multicolumn{2}{|c|}{ Intercept Term $\left(\hat{\delta}_{0 i j}\right)$} & \multicolumn{2}{|c|}{ Growth in Demand $\left(\hat{\delta}_{1 i j}\right)$} & \multicolumn{2}{|c|}{ Growth in SMP $\left(\hat{\delta}_{2 i j}\right)$} \\
\hline & & Coef. & Std. Err. & Coef. & Std. Err. & Coef. & Std. Err \\
\hline \multirow{6}{*}{ 号 } & Large Coal & $-0.2912 * * *$ & 0.0594 & $1.4525 * * *$ & 0.2761 & $-0.1253^{* * *}$ & 0.0342 \\
\hline & Medium Coal & $-0.3561 * * *$ & 0.0588 & $1.6207 * * *$ & 0.2753 & $-0.0793 * * *$ & 0.0286 \\
\hline & Small Coal & $-0.4017 * * *$ & 0.0675 & $1.9308^{* * *}$ & 0.3328 & $-0.0995 * * *$ & 0.0348 \\
\hline & Oil & $-0.3029 * * *$ & 0.0591 & $1.4407 * * *$ & 0.2751 & $-0.1223 * * *$ & 0.0340 \\
\hline & CCGT & $-0.6633 * * *$ & 0.0664 & $4.0860 * * *$ & 0.3201 & $-0.0609^{*}$ & 0.0316 \\
\hline & OCGT & $-0.4417 * * *$ & 0.0591 & $1.7956 * * *$ & 0.2752 & $-0.0999 * * *$ & 0.0320 \\
\hline \multirow{5}{*}{$\begin{array}{l}\circlearrowright \\
\text { D }\end{array}$} & Large Coal & $-0.3238 * * *$ & 0.0593 & $1.2862 * * *$ & 0.2710 & $-0.0991 * * *$ & 0.0320 \\
\hline & Medium Coal & $-0.3091 * *$ & 0.1422 & $2.6051 * * *$ & 0.8487 & $-0.2244 * *$ & 0.1028 \\
\hline & Oil & $-0.2723 * * *$ & 0.0636 & $0.8712^{* * *}$ & 0.2919 & $-0.0722 * *$ & 0.0348 \\
\hline & CCGT & $-0.5000 * * *$ & 0.0645 & $3.6059 * * *$ & 0.3091 & $-0.0625^{*}$ & 0.0352 \\
\hline & OCGT & $-0.2696 * * *$ & 0.0589 & $0.7523 * * *$ & 0.2683 & $-0.0856 * * *$ & 0.0309 \\
\hline \multirow{4}{*}{ 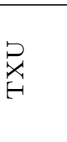 } & Large Coal & -0.1249 & 0.0794 & $-1.9103 * * *$ & 0.3893 & $-0.2642 * * *$ & 0.0534 \\
\hline & Medium Coal & $-0.2061 * *$ & 0.0867 & $-1.3980 * * *$ & 0.4225 & $-0.2584 * * *$ & 0.0586 \\
\hline & CCGT & $-0.5482 * * *$ & 0.0676 & $3.3143^{* * *}$ & 0.3229 & $-0.1263 * * *$ & 0.0368 \\
\hline & OCGT & -0.1034 & 0.0825 & $-2.8633 * * *$ & 0.4164 & $-0.2107 * * *$ & 0.0550 \\
\hline \multirow{3}{*}{ 藏 } & Large Coal & $-0.3352 *$ & 0.1718 & $-2.9061 * * *$ & 0.7771 & -0.0415 & 0.1100 \\
\hline & OCGT & $0.3800 *$ & 0.2070 & $-8.6513 * * *$ & 1.0667 & -0.1312 & 0.1249 \\
\hline & PSB & -0.1460 & 0.1428 & $-8.1239 * * *$ & 0.7762 & -0.0243 & 0.0800 \\
\hline \multirow{2}{*}{ 됨 } & Large Coal & 0.0925 & 0.2088 & $-1.9343^{* *}$ & 0.8440 & -0.1222 & 0.1146 \\
\hline & Nuclear & $-0.4896 * * *$ & 0.0788 & $0.7986 * *$ & 0.3516 & 0.0414 & 0.0405 \\
\hline \multirow{5}{*}{$\begin{array}{l}\text { 足 } \\
\text { 要 }\end{array}$} & Large Coal & -0.1242 & 0.1542 & $2.0221 * * *$ & 0.6194 & -0.1465 & 0.0923 \\
\hline & CCGT & -0.1130 & 0.1197 & $3.9276 * * *$ & 0.5510 & $-0.3011 * * *$ & 0.0676 \\
\hline & OCGT & -0.0136 & 0.1120 & $2.4559 * * *$ & 0.4978 & $-0.2547 * * *$ & 0.0614 \\
\hline & Obs. & 29,436 & & & & & \\
\hline & Pseudo $R^{2}$ & 0.0818 & & & & & \\
\hline
\end{tabular}

Notes: Robust standard errors are used for statistical inferences. *, **, and *** stand for the 10\%, 5\%, and $1 \%$ significance levels, respectively.

particular, we find that demand increases incentivize the incumbents to decide to apply capacity cutting (Decision $=1$ corresponds to the cutting case), whereas wholesale price increases tend to restrain their decision to apply capacity cutting. We also find that the incentive to decide to cut for the CCGT type is the largest for both incumbents. This sheds light on incumbent producers' differing attitudes in the decision to apply capacity cutting across various types of production capacity.

The findings for the incumbent producers are also qualitatively true for the CCGT type belonging to TXU, the nuclear type belonging to British Energy (BE), and all capacity types belonging to AES.

Negative slope coefficients for demand increases can be interpreted as a producer's 
differing decision attitudes for large and small demand increases. That is, if a large increase in demand is expected, then a producer is more tempted to decide for expanding than for cutting. This is found for coal, OCGT types belonging to TXU, all types belonging to Edison, and the coal type of production capacity belonging to BE. We explain these findings by the fact that TXU, Edison, and BE are new entrants. In particular, it was TXU and Edison which received plants in the divestment series and thereby became major power producers. BE was created after the privatization of some nuclear plants completed in the summer 1995.

We also find that an expected larger price increase, compared to a demand increase, inclines all producers towards deciding to expand production capacity. This follows from the negativity of the estimated slope parameter in front of the SMP increase across almost all producers and capacity types. An exception is the nuclear capacity belonging to BE. Its estimated slope parameter is, however, statistically insignificant.

The fitted values of the probit selection equation are used in calculating the inverse of Mill's ratio, which is included as an additional explanatory variable in the amount equations describing the cutting and expanding behaviors of producers.

\subsection{Amount Equations}

In estimating the amount equations we further assume that the producer and capacity type specific parameters may vary during the different regulatory regime periods described in Section 2. In Table 6.2 and Table 6.3 we present the estimation results for the cutting and expanding amount equations. 
Table 6.2: Amount Equation for the Cutting Case

$s_{i j t}^{H}-s_{i j t}^{L}=\alpha_{0 i j}+\alpha_{1 i j} \cdot$ growth in demand $_{t}+\gamma_{C} \cdot \hat{\lambda}_{i j t}^{C}+\varepsilon_{i j t}$

\begin{tabular}{|c|c|c|c|c|c|c|c|c|c|c|}
\hline \multicolumn{5}{|c|}{ Dep. Var.: Amount } & \multicolumn{2}{|c|}{ Pre-Regime 4} & \multicolumn{2}{|c|}{ Regime 4} & \multicolumn{2}{|c|}{ Regime 5} \\
\hline & & Jariable & Coef. & Std. Err. & Coef. & Std. Err. & Coef. & Std. Err. & Coef. & Std. Err. \\
\hline \multirow{23}{*}{ 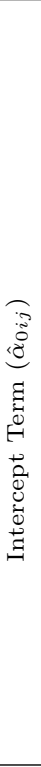 } & \multirow{6}{*}{ 号 } & Large Coal & 0.0061 & 0.0095 & $-0.0041 * * *$ & 0.0001 & $-0.0035 * * *$ & 0.0002 & $-0.0241 * * *$ & 0.0003 \\
\hline & & Medium Coal & 0.0086 & 0.0098 & $-0.0073 * * *$ & 0.0001 & $-0.0046 * * *$ & 0.0001 & $-0.0215 * * *$ & 0.0002 \\
\hline & & Small Coal & -0.0041 & 0.0101 & $0.0174 * * *$ & 0.0001 & $0.0091 * * *$ & 0.0002 & & \\
\hline & & Oil & 0.0070 & 0.0096 & $-0.0017 * * *$ & 0.0001 & $-0.0097 * * *$ & 0.0002 & $-0.0197 * * *$ & 0.0003 \\
\hline & & CCGT & $-0.0523 * * *$ & 0.0113 & $0.1447 * * *$ & 0.0002 & $0.0419 * * *$ & 0.0001 & $0.0210 * * *$ & 0.0001 \\
\hline & & OCGT & 0.0091 & 0.0104 & $-0.0052 * * *$ & 0.0002 & $-0.0035 * * *$ & 0.0001 & $-0.0184 * * *$ & 0.0003 \\
\hline & \multirow{5}{*}{ שֶ } & Large Coal & -0.0002 & 0.0097 & $-0.0267^{* * *}$ & 0.0001 & $0.0009^{* * *}$ & 0.0000 & $0.0075^{* * *}$ & 0.0001 \\
\hline & & Medium Coal & -0.0003 & 0.0100 & $-0.0162 * * *$ & 0.0002 & & & & \\
\hline & & Oil & -0.0054 & 0.0093 & $-0.0342 * * *$ & 0.0000 & $0.0076 * * *$ & 0.0000 & $0.0133 * * *$ & 0.0000 \\
\hline & & CCGT & -0.0034 & 0.0103 & $-0.0208 * * *$ & 0.0001 & $-0.0084 * * *$ & 0.0000 & $0.0083 * * *$ & 0.0002 \\
\hline & & OCGT & 0.0026 & 0.0093 & $-0.0206 * * *$ & 0.0002 & $-0.0004 * * *$ & 0.0000 & $0.0060 * * *$ & 0.0001 \\
\hline & \multirow{4}{*}{$\stackrel{D}{x}$} & Large Coal & -0.0089 & 0.0087 & & & & & $-0.0094 * * *$ & 0.0009 \\
\hline & & Medium Coal & 0.0058 & 0.0092 & & & & & $-0.0280 * * *$ & 0.0004 \\
\hline & & CCGT & $-0.0536 * * *$ & 0.0108 & $0.0927 * * *$ & 0.0002 & $-0.0123 * * *$ & 0.0002 & $0.0813 * * *$ & 0.0005 \\
\hline & & OCGT & $-0.0156^{*}$ & 0.0083 & & & & & $-0.0035 * * *$ & 0.0006 \\
\hline & \multirow{3}{*}{ 啬 } & Large Coal & $-0.0340 * * *$ & 0.0096 & & & & & & \\
\hline & & OCGT & $-0.0168 * * *$ & 0.0049 & & & & & & \\
\hline & & PSB & $-0.0264 * * *$ & 0.0080 & & & & & $0.0148 * * *$ & 0.0000 \\
\hline & \multirow{2}{*}{ 됨 } & Large Coal & -0.0028 & 0.0074 & & & & & & \\
\hline & & Nuclear & -0.0003 & 0.0104 & & & $-0.0123 * * *$ & 0.0001 & $0.0033 * * *$ & 0.0001 \\
\hline & \multirow{3}{*}{ 告 } & Large Coal & 0.0132 & 0.0088 & & & & & & \\
\hline & & CCGT & -0.0039 & 0.0086 & & & & & $-0.0197 * * *$ & 0.0004 \\
\hline & & OCGT & $-0.0272^{* * *}$ & 0.0081 & & & & & $0.0399 * * *$ & 0.0005 \\
\hline \multirow{26}{*}{ 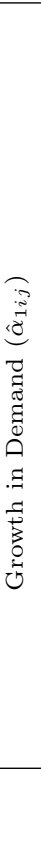 } & \multirow{6}{*}{ 号 } & Large Coal & $-0.0499 * * *$ & 0.0058 & $0.0281 * * *$ & 0.0008 & $0.0199 * * *$ & 0.0010 & $0.0478 * * *$ & 0.0023 \\
\hline & & Medium Coal & $-0.0861 * * *$ & 0.0078 & $0.0712 * * *$ & 0.0005 & $0.0509 * * *$ & 0.0008 & $0.0696 * * *$ & 0.0011 \\
\hline & & Small Coal & $-0.0189^{*}$ & 0.0092 & $-0.0775 * * *$ & 0.0007 & $-0.0220 * * *$ & 0.0009 & & \\
\hline & & Oil & $-0.0439 * * *$ & 0.0058 & $0.0143 * * *$ & 0.0007 & $0.0492 * * *$ & 0.0012 & $0.0523 * * *$ & 0.0023 \\
\hline & & CCGT & $-0.1823 * * *$ & 0.0208 & $-0.3786 * * *$ & 0.0006 & $0.0703^{* * *}$ & 0.0003 & $0.2186 * * *$ & 0.0008 \\
\hline & & OCGT & $-0.0454 * * *$ & 0.0087 & $0.0268 * * *$ & 0.0010 & $0.0211^{* * *}$ & 0.0009 & $0.0517^{* * *}$ & 0.0017 \\
\hline & \multirow{5}{*}{$\begin{array}{l}\text { J } \\
\text { L }\end{array}$} & Large Coal & -0.0049 & 0.0059 & $0.0963 * * *$ & 0.0003 & $-0.0269 * * *$ & 0.0000 & $-0.0412^{* * *}$ & 0.0005 \\
\hline & & Medium Coal & -0.0081 & 0.0124 & $0.0728 * * *$ & 0.0028 & & & & \\
\hline & & Oil & 0.0005 & 0.0040 & $0.0794 * * *$ & 0.0005 & $-0.0210 * * *$ & 0.0002 & $-0.0422 * * *$ & 0.0002 \\
\hline & & CCGT & $-0.1332 * * *$ & 0.0176 & $-0.1359 * * *$ & 0.0005 & $0.0480 * * *$ & 0.0000 & $0.0437 * * *$ & 0.0010 \\
\hline & & OCGT & -0.0049 & 0.0030 & $0.0801 * * *$ & 0.0001 & $-0.0190 * * *$ & 0.0002 & $-0.0354 * * *$ & 0.0003 \\
\hline & \multirow{4}{*}{ 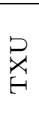 } & Large Coal & -0.0073 & 0.0189 & & & & & $-0.0945 * * *$ & 0.0047 \\
\hline & & Medium Coal & $-0.2780 * * *$ & 0.0155 & & & & & $0.3131 * * *$ & 0.0018 \\
\hline & & CCGT & $0.0707 * * *$ & 0.0157 & $-0.5316 * * *$ & 0.0014 & $-0.3100 * * *$ & 0.0009 & $-0.8598 * * *$ & 0.0025 \\
\hline & & OCGT & 0.0218 & 0.0256 & & & & & 0.0038 & 0.0032 \\
\hline & \multirow{3}{*}{ 苛 } & Large Coal & 0.0116 & 0.0220 & & & & & & \\
\hline & & OCGT & 0.0907 & 0.0648 & & & & & & \\
\hline & & PSB & -0.0668 & 0.0616 & & & & & $0.1490 * * *$ & 0.0008 \\
\hline & \multirow{2}{*}{ 红 } & Large Coal & -0.0165 & 0.0143 & & & & & & \\
\hline & & Nuclear & $0.0228 * * *$ & 0.0065 & & & $-0.0358 * * *$ & 0.0004 & $-0.0989 * * *$ & 0.0008 \\
\hline & \multirow{6}{*}{$\begin{array}{l}\text { 告 } \\
\text { 出 }\end{array}$} & Large Coal & $-0.0750 * * *$ & 0.0102 & & & & & & \\
\hline & & CCGT & $-0.1334 * * *$ & 0.0160 & & & & & $0.1422 * * *$ & 0.0009 \\
\hline & & OCGT & $-0.0500 * * *$ & 0.0102 & & & & & $-0.0247 * * *$ & 0.0012 \\
\hline & & $\hat{\gamma}_{C}$ & $-0.0164 *$ & 0.0093 & & & & & & \\
\hline & & Obs. & 11,812 & & & & & & & \\
\hline & & $R^{2}$ & 0.3074 & & & & & & & \\
\hline
\end{tabular}

Notes: The last three columns contain coefficient estimates for interaction terms with regime dummy variables. Clustered standard errors are used for statistical inferences. *, **, and *** stand for the $10 \%$, $5 \%$, and $1 \%$ significance levels, respectively. 
Table 6.3: Amount Equation for the Expanding Case

$s_{i j t}^{H}-s_{i j t}^{L}=\beta_{0 i j}+\beta_{1 i j} \cdot$ growth in demand $_{t}+\gamma_{E} \cdot \hat{\lambda}_{i j t}^{E}+\epsilon_{i j t}$

\begin{tabular}{|c|c|c|c|c|c|c|c|c|c|c|}
\hline \multicolumn{5}{|c|}{ Dep. Var.: Amount } & \multicolumn{2}{|c|}{ Pre-Regime 4} & \multicolumn{2}{|c|}{ Regime 4} & \multicolumn{2}{|c|}{ Regime 5} \\
\hline & & Variable & Coef. & Std. Err. & Coef. & Std. Err. & Coef. & Std. Err. & Coef. & Std. Err. \\
\hline \multirow{23}{*}{ 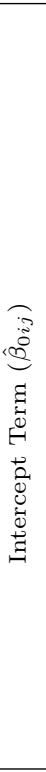 } & \multirow{6}{*}{ 号 } & Large Coal & $0.0389 * * *$ & 0.0112 & $0.0188 * * *$ & 0.0003 & $-0.0036 * * *$ & 0.0000 & $-0.0049 * * *$ & 0.0004 \\
\hline & & Medium Coal & $0.0393^{* * *}$ & 0.0107 & $0.0102 * * *$ & 0.0001 & $-0.0056 * * *$ & 0.0000 & $-0.0244 * * *$ & 0.0003 \\
\hline & & Small Coal & $0.0408 * * *$ & 0.0101 & $0.0056 * * *$ & 0.0003 & $-0.0081 * * *$ & 0.0000 & & \\
\hline & & Oil & $0.0366 * * *$ & 0.0111 & $0.0146 * * *$ & 0.0002 & $-0.0088 * * *$ & 0.0000 & $-0.0032 * * *$ & 0.0004 \\
\hline & & CCGT & $0.1015 * * *$ & 0.0073 & $0.0329 * * *$ & 0.0002 & $-0.0402 * * *$ & 0.0005 & $-0.0769 * * *$ & 0.0008 \\
\hline & & OCGT & $0.0338 * * *$ & 0.0097 & $0.0090 * * *$ & 0.0001 & $-0.0032 * * *$ & 0.0000 & $-0.0026 * * *$ & 0.0004 \\
\hline & \multirow{5}{*}{$\begin{array}{l}\text { Ju } \\
\text { L }\end{array}$} & Large Coal & 0.0160 & 0.0110 & $0.0421 * * *$ & 0.0005 & $0.0200^{* * *}$ & 0.0001 & $0.0115^{* * *}$ & 0.0005 \\
\hline & & Medium Coal & $0.0348 * * *$ & 0.0104 & $0.0165 * * *$ & 0.0013 & & & & \\
\hline & & Oil & $-0.0355 * * *$ & 0.0117 & $0.0695 * * *$ & 0.0003 & $0.0606 * * *$ & 0.0002 & $0.0623 * * *$ & 0.0005 \\
\hline & & CCGT & $0.0266 * * *$ & 0.0087 & $0.0728 * * *$ & 0.0005 & $0.0044 * * *$ & 0.0001 & $-0.0007^{*}$ & 0.0004 \\
\hline & & OCGT & -0.0092 & 0.0117 & $0.0568 * * *$ & 0.0005 & $0.0391 * * *$ & 0.0001 & $0.0363 * * *$ & 0.0005 \\
\hline & \multirow{4}{*}{$\stackrel{己}{\stackrel{x}{E}}$} & Large Coal & -0.0163 & 0.0112 & & & & & $0.0594^{* * *}$ & 0.0002 \\
\hline & & Medium Coal & $-0.0270 * *$ & 0.0107 & & & & & $0.1203 * * *$ & 0.0006 \\
\hline & & CCGT & $0.0556 * * *$ & 0.0087 & $0.1461 * * *$ & 0.0023 & $-0.0738 * * *$ & 0.0006 & 0.0016 & 0.0011 \\
\hline & & OCGT & -0.0174 & 0.0112 & & & & & $0.0576 * * *$ & 0.0002 \\
\hline & \multirow{3}{*}{ 总 } & Large Coal & $0.0604^{* * *}$ & 0.0101 & & & & & & \\
\hline & & OCGT & -0.0146 & 0.0114 & & & & & & \\
\hline & & PSB & $0.0930 * * *$ & 0.0067 & & & & & $-0.1170 * * *$ & 0.0008 \\
\hline & \multirow{2}{*}{ II } & Large Coal & $0.0475 * * *$ & 0.0145 & & & & & & \\
\hline & & Nuclear & $0.0278 * *$ & 0.0100 & & & $0.0120 * * *$ & 0.0000 & $0.0095 * * *$ & 0.0001 \\
\hline & \multirow{3}{*}{$\begin{array}{l}\text { 吸 } \\
\text { 至 }\end{array}$} & Large Coal & $0.0296 * *$ & 0.0122 & & & & & & \\
\hline & & CCGT & $0.0580 * * *$ & 0.0130 & & & & & $-0.0263 * * *$ & 0.0025 \\
\hline & & OCGT & $0.0928 * * *$ & 0.0144 & & & & & $-0.0625 * * *$ & 0.0020 \\
\hline \multirow{26}{*}{ 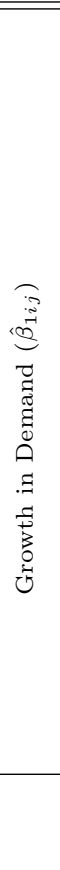 } & \multirow{6}{*}{ 号 } & Large Coal & $20.0680 * * *$ & 0.0109 & $-0.0602 * * *$ & 0.0020 & $0.0341 * * *$ & 0.0002 & $0.1888^{* * *}$ & 0.0026 \\
\hline & & Medium Coal & $0.0830 * * *$ & 0.0152 & $-0.0323 * * *$ & 0.0013 & $0.0185 * * *$ & 0.0001 & $0.4991^{* * *}$ & 0.0026 \\
\hline & & Small Coal & $0.0908 * * *$ & 0.0178 & $-0.0199 * * *$ & 0.0019 & $0.0146 * * *$ & 0.0005 & & \\
\hline & & Oil & $0.0750 * * *$ & 0.0110 & $-0.0585 * * *$ & 0.0021 & $0.0818 * * *$ & 0.0000 & $0.1299 * * *$ & 0.0025 \\
\hline & & CCGT & $0.2160 * * *$ & 0.0443 & $-0.0216 * * *$ & 0.0018 & $0.0756 * * *$ & 0.0040 & $0.1029 * * *$ & 0.0063 \\
\hline & & OCGT & $0.0845 * * *$ & 0.0157 & $-0.0355 * * *$ & 0.0011 & $0.0050 * * *$ & 0.0001 & $0.1280 * * *$ & 0.0026 \\
\hline & \multirow{5}{*}{$\begin{array}{l}U \\
\sim\end{array}$} & Large Coal & $0.3765 * * *$ & 0.0099 & $-0.3343^{* * *}$ & 0.0024 & $-0.2555 * * *$ & 0.0011 & $-0.1909 * * *$ & 0.0041 \\
\hline & & Medium Coal & $0.1586 * * *$ & 0.0211 & $-0.1263 * * *$ & 0.0099 & & & & \\
\hline & & Oil & $1.0598 * * *$ & 0.0062 & $0.2561 * * *$ & 0.0011 & $-0.7362 * * *$ & 0.0018 & $-0.8921 * * *$ & 0.0032 \\
\hline & & CCGT & $0.3428 * * *$ & 0.0432 & $-0.1773 * * *$ & 0.0016 & $-0.0773 * * *$ & 0.0001 & $-0.1171 * * *$ & 0.0023 \\
\hline & & OCGT & $0.5882 * * *$ & 0.0044 & $-0.2352 * * *$ & 0.0023 & $-0.4356 * * *$ & 0.0010 & $-0.4321 * * *$ & 0.0034 \\
\hline & \multirow{4}{*}{$\stackrel{D}{x}$} & Large Coal & $1.0276^{* * *}$ & 0.0198 & & & & & $-0.2979 * * *$ & 0.0012 \\
\hline & & Medium Coal & $1.2074 * * *$ & 0.0169 & & & & & $-0.7554 * * *$ & 0.0031 \\
\hline & & CCGT & $0.9120 * * *$ & 0.0294 & $-1.1057 * * *$ & 0.0094 & $0.0734 * * *$ & 0.0049 & $-0.6039 * * *$ & 0.0079 \\
\hline & & OCGT & $1.0224 * * *$ & 0.0232 & & & & & $-0.3585 * * *$ & 0.0008 \\
\hline & \multirow{3}{*}{ 苛 } & Large Coal & $0.3894^{* * *}$ & 0.0202 & & & & & & \\
\hline & & OCGT & $0.9998 * * *$ & 0.0339 & & & & & & \\
\hline & & PSB & $1.4599 * * *$ & 0.0190 & & & & & $-0.4162 * * *$ & 0.0034 \\
\hline & \multirow{2}{*}{ II } & Large Coal & $0.0993 * * *$ & 0.0209 & & & & & & \\
\hline & & Nuclear & $0.0237 * *$ & 0.0103 & & & $-0.0048 * * *$ & 0.0001 & $0.0016^{* *}$ & 0.0007 \\
\hline & \multirow{6}{*}{$\begin{array}{l}0 \\
\text { 至 } \\
\end{array}$} & Large Coal & $0.1659^{* * *}$ & 0.0225 & & & & & & \\
\hline & & CCGT & $0.3952 * * *$ & 0.0250 & & & & & $-0.0480 * *$ & 0.0189 \\
\hline & & OCGT & $0.1674 * * *$ & 0.0113 & & & & & -0.0015 & 0.0147 \\
\hline & & $\hat{\gamma}_{E}$ & $-0.0411^{* *}$ & 0.0191 & & & & & & \\
\hline & & Obs. & 17,624 & & & & & & & \\
\hline & & $R^{2}$ & 0.6574 & & & & & & & \\
\hline
\end{tabular}

Notes: The last three columns contain coefficient estimates for interaction terms with regime dummy variables. Clustered standard errors are used for statistical inferences. *, **, and *** stand for the $10 \%$, $5 \%$, and $1 \%$ significance levels, respectively. 
The two amount equations describing cutting and expanding behaviors are estimated separately using the selected two samples. Because the cutting and expanding samples are selected nonrandomly in our research, we may have a sample selection bias problem. This means that not accounting for the sample selection problem may lead to biased parameter estimates in the amount equations. For this reason we have applied Heckman's two-step procedure.

Our results indicate that the null hypothesis stating no sample selection problem is rejected at the $10 \%$ significance level for each amount equation. This finding justifies the validity of including into the amount equations the inverse of Mill's ratio in order to correct for sample selection bias.

The incentive of how much to cut or expand when demand increases is reflected by producer/capacity type specific slope parameters in the amount equations presented in Table 6.2 and Table 6.3, respectively.

In the following sections we first discuss estimation results for the incumbent electricity producers. We then discuss in detail the findings for the TXU and Edison producers, which received plants during the divestment series. We conclude our discussion with the British Energy and AES producers.

\subsubsection{Incumbent Producers}

Based on the estimation results presented in Table 6.2 we find that NP's incentive to apply capacity cutting has declined (indicating success of the introduced divestment series) for almost all types during regime 4 and regime 5 . An exception is the small coal type for which the incentive increased during the pre-regime 4 and regime 4 periods. PG's incentive to apply capacity cutting, however, increased for almost all types (an exception is the CCGT type) in the last two regime periods.

We also find that during pre-regime 4 the bidding behavior of both incumbents is 
consistent with indirect capacity cutting, because the incentive to increase production capacity when demand increases declined. This behavior continued to prevail for PG even after the divestment series were introduced. However, the incentive to expand production during the peak-demand trading periods monotonically increased for NP.

The regulatory actions, therefore, did not have the same effect on the incumbents' bidding behavior. We explain the observed contrasting effects of the regulatory reforms as the consequence of an unequal horizontal restructuring introduced through divestment series. Based on our estimation results we conclude that the divestment series were successful in disciplining the bidding behavior of only the larger incumbent producer.

\subsubsection{TXU and Edison}

TXU is the producer which received plants during the first series of divestments. We find that for TXU the incentive to cut capacity increased with respect to large coal and CCGT types and decreased with respect to the medium coal type during regime 5 . There is no statistical evidence that demand increases are associated with capacity cutting for the OCGT type. Similar to the second incumbent producer, TXU's bidding behavior is also consistent with indirect capacity cutting, because the incentive to expand production as a response to demand increases declined in the last regime period.

Edison is the producer which received plants during the second series of divestments. Findings for this producer do not indicate that demand increases are associated with capacity cutting, because the estimated slope parameters for this producer are statistically insignificant. We also find that this producer's bidding behavior with respect to large coal and OCGT capacity types is consistent with expanding production when demand increases. However, the incentive to expand production capacity when demand increases declined for the PSB type during regime 5. 


\subsubsection{British Energy and AES}

During the last two regime periods the bidding behavior of BE with respect to the nuclear type is found to be consistent with applying capacity cutting. This finding is in line with the conjecture in Fridolfsson and Tangerås (2009) and may explain why BE refused to sign the market abuse license condition (MALC). ${ }^{4}$ We also find that during regime 4 BE's incentive to expand production declined, which is interpreted as evidence of indirect capacity cutting. However, during the last regime period the incentive increased.

The second producer which did not sign the MALC was AES. Its incentive to apply capacity cutting also increased with respect to the OCGT type. Nevertheless, the incentive decreased with respect to the CCGT type, which could have been the result of the increased regulatory oversight. However, during regime 5 the incentive of AES to expand production declined with respect to CCGT and OCGT production capacity.

\section{Conclusions}

Using the case of the England and Wales electricity market, we analyze whether producers can apply a capacity cutting strategy to increase prices at a uniform price auction. We find statistical evidence for the presence of direct and indirect capacity cutting strategies as a response to demand increases. These strategies allow producers to artificially create deficit and increase wholesale electricity prices and hence profits. The regulatory reforms targeted at disciplining the bidding behavior of the incumbent electricity producers are found to affect differently and sometimes in opposite directions. We explain this as the consequence of an unequal horizontal restructuring. The divestment series are generally

\footnotetext{
${ }^{4}$ The regulatory authority proposed a license condition targeted at tackling market abuse in 2000. Because two major electricity producers, British Energy and AES, refused to accept the MALC, the regulatory authority referred the matter to the Competition Commission (CC). The CC subsequently did not approve the introduction of the MALC, although it acknowledged the possibility that British Energy could profit from capacity cutting (OFGEM, December 11, 2000b).
} 
found to be successful in disciplining the bidding behavior of only the larger incumbent producer.

We also find that the BE and AES producers, which refused to sign the MALC, were involved in manipulating capacity bids. This partly explains why these producers did not agree to sign the MALC.

An application of Heckman's two-step procedure is justified by the statistical significance of the inverse of Mill's ratio included in the amount equations. This is important because the cutting and expanding samples considered in our research are selected nonrandomly. In this way it has become possible to estimate model parameters free of sample selection bias. 


\section{References}

Bergman, L., C. Doyle, J. Gual, L. Hultkrantz, D. Neven, L.-H. Röller, and L. Waverman, Europe's Network Industries: Conflicting Priorities - Telecommunications, Vol. 1 of Monitoring European Deregulation, London, UK: Center for Economic Policy Research, 1998.

Bishop, S. and C. McSorley, "Regulating Electricity Markets: Experience from the United Kingdom," The Electricity Journal, 2001, 14 (10), 81-86.

Borenstein, S., J. B. Bushnell, and F. A. Wolak, "Measuring Market Inefficiencies in California's Restructured Wholesale Electricity Market," The American Economic Review, 2002, 92 (5), 1376-1405.

Brazil: Destroy! Destroy!, Time Magazine - U.S. Edition, June 6, 1932, 19 (23).

Castro-Rodriguez, F., P. L. Marín, and G. Siotis, "Capacity Choices in Liberalized Electricity Markets," Energy Policy, 2009, 37 (7), 2574-2581.

Ceni na solyarku: polniy absurd i naglost - Prices of Diesel Fuel: Complete Absurdity and Impudence, Avtonovosti - Automobile News. Retrieved from http://auto.mail.ru/article.html?id=34055, April 14, 2011.

Crampes, C. and A. Creti, "Capacity Competition in Electricity Markets," GRE$M A Q, I D E I, I E F E, 2006$, pp. 1-28.

Crawford, G. S., J. Crespo, and H. Tauchen, "Bidding Asymmetries in MultiUnit Auctions: Implications of Bid Function Equilibria in the British Spot Market for Electricity," International Journal of Industrial Organization, 2007, 25 (6), 1233-1268.

Department of Trade and Industry, Digest of United Kingdom Energy Statistics, London, UK: The Stationery Office, 1997-2002.

Electricity Pool, "Pooling and Settlement Agreement for the Electricity Industry in England and Wales," 1990.

European Commission, "Summary of Commission Decision of 26 November 2008 relating to a proceeding under Article 82 of the EC Treaty and Article 54 of the EEA Agreement (Cases COMP/39.388 - German Electricity Wholesale Market and COMP/39.389 - German Electricity Balancing Market)," Official Journal of the European Union, February 13, 2009, 52 (C 36), 8.

Fridolfsson, S.-O. and T. P. Tangerås, "Market Power in the Nordic Electricity Wholesale Market: A Survey of the Empirical Evidence," Energy Policy, 2009, 37 (9), 3681-3692. 
Green, R. J., "Did English Generators Play Cournot? Capacity Withholding in the Electricity Pool," MIT Center for Energy and Environmental Policy Research, WP 04-010, 2004, pp. 1-21.

_ , "Market Power Mitigation in the UK Power Market," Utilities Policy, 2006, 14 (2), 76-89.

- and D. M. Newbery, "Competition in the British Electricity Spot Market," Journal of Political Economy, 1992, 100 (5), 929-953.

Heckman, J. J., "Sample Selection Bias as a Specification Error," Econometrica, 1979, $47(1), 153-161$.

Joskow, P. L., "Foreword: US vs. EU Electricity Reforms Achievement," in J.-M. Glachant and F. Lévêque, eds., Electricity Reform in Europe, Cheltenham, UK: Edward Elgar Publishing Limited, 2009.

- and E. Kohn, "A Quantitative Analysis of Pricing Behavior in California's Wholesale Electricity Market during Summer 2000," The Energy Journal, 2002, 23 (4), 1-36.

Kmenta, J., Elements of Econometrics, Michigan, USA: The University of Michigan Press, 2004.

Le Coq, C., "Strategic Use of Available Capacity in the Electricity Spot Market," SSE/EFI Working Paper No. 496, 2002, pp. 1-27.

National Grid Company, Seven Year Statement, London, UK: National Grid Company, 1994-2001.

Newbery, D. M., "The UK Experience: Privatization with Market Power," University of Cambridge, Mimeo, 1999, pp. 1-23.

OFGEM, December 11, 2000.

Competition Commission Rejects Market Abuse Licence Condition.

- , July 12, 2000.

OFGEM's Investigation of Edison First Power under the Market Abuse License Condition: Initial Findings.

Robinson, T. and A. Baniak, "The Volatility of Prices in the English and Welsh Electricity Pool," Applied Economics, 2002, 34 (12), 1487-1495.

Sanin, M. E., "Market Design in Wholesale Electricity Markets," CORE Discussion Paper 2006/100, 2006, pp. 1-21.

Sweeting, A., "Market Power in the England and Wales Wholesale Electricity Market 1995-2000," The Economic Journal, 2007, 117 (520), 654-685. 
Von der Fehr, N.-H. M. and D. Harbord, "Spot Market Competition in the UK Electricity Industry," The Economic Journal, 1993, 103 (418), 531-546.

Weare, C., The California Electricity Crisis: Causes and Policy Options, San Francisco, USA: Public Policy Institute of California, 2003.

Wolak, F. A., "Market Design and Price Behavior in Restructured Electricity Markets: An International Comparison," Deregulation and Interdependence in the Asia-Pacific Region, NBER-EASE, 2000, 8, 79-137.

- and R. H. Patrick, "The Impact of Market Rules and Market Structure on the Price Determination Process in the England and Wales Electricity Market," NBER Working Paper No. W8248, 2001, pp. 1-86.

Wolfram, C. D., "Strategic Bidding in a Multiunit Auction: An Empirical Analysis of Bids to Supply Electricity in England and Wales," The RAND Journal of Economics, 1998, 29 (4), 703-725.

_ , "Measuring Duopoly Power in the British Electricity Spot Market," The American Economic Review, 1999, 89 (4), 805-826. 


\section{Appendices}

\section{A Profit Accounting}

In order to better understand the cutting and expanding decisions of producers during high-demand periods relative to low-demand periods, we analyze the profits of producers during different trading periods. This should shed light on what factor(s) could be explaining producers' capacity cutting or expanding decisions.

Profits of a producer during low- and high-demand trading periods are presented in the following equations:

$$
\begin{aligned}
& \pi^{L}=\mathrm{SMP}^{L} \cdot \sum_{i} \frac{1}{2} q_{i}^{L}-\sum_{i} \mathrm{MC}_{i} \cdot \frac{1}{2} q_{i}^{L} \\
& \pi^{H}=\mathrm{SMP}^{H} \cdot \sum_{i} \frac{1}{2} \alpha_{i}^{H} q_{i}^{L}-\sum_{i} \mathrm{MC}_{i} \cdot \frac{1}{2} \alpha_{i}^{H} q_{i}^{L}
\end{aligned}
$$

In these equations SMP is a wholesale price (measured in $£ / \mathrm{MWh}$ ), MC is marginal production cost (measured in $£ / M W h), q$ is production capacity (measured in MW). A factor of $\frac{1}{2}$ is used to compute how much electricity (measured in MWh) can be produced during a half-hour period. In our notation $\alpha_{i}^{H}<1$ corresponds to cutting and $\alpha_{i}^{H}>1$ corresponds to expanding decisions.

Taking the difference and rearranging the terms leads to:

$$
\begin{aligned}
& \pi^{H}-\pi^{L}=\sum_{i} \frac{1}{2} q_{i}^{L}\left[\mathrm{SMP}^{L}\left(\frac{\mathrm{SMP}^{H}}{\mathrm{SMP}^{L}} \cdot \alpha_{i}^{H}-1\right)-\mathrm{MC}_{i}\left(\alpha_{i}^{H}-1\right)\right] \approx \\
& \approx \sum_{i} \frac{1}{2} q_{i}^{L} \cdot \mathrm{MC}_{i} \alpha_{i}^{H}\left(\frac{\mathrm{SMP}^{H}}{\mathrm{SMP}^{L}}-1\right) \geq 0
\end{aligned}
$$

The approximation serves to obtain an estimate of the profit difference when we compare high- and low-demand trading periods, where we assume that $\mathrm{SMP}^{L} \approx \mathrm{MC}_{i}$.

In the last line we observe that $\frac{\mathrm{SMP}^{H}}{\mathrm{SMP}^{L}}-1$, which represents a relative change in the wholesale price during a high-demand trading period compared to a low-demand 
trading period, also affects the profit differential. Specifically, if a producer expects a large increase in the wholesale price, then there should be less incentive to decide towards capacity cutting (that is, to decide $\alpha_{i}^{H}<1$ ) and more incentive to decide towards increasing production (that is, to decide $\alpha_{i}^{H}>1$ ). Based on this observation, we decided to include $\frac{\mathrm{SMP}^{H}}{\mathrm{SMP}^{L}}-1$ as another explanatory variable (in addition to demand increase explanatory variable) in the selection equation. The prediction that if a producer expects a large increase in the wholesale price, then there should be more incentive to decide towards capacity expanding, is verifiable by hypothesis testing. 


\section{B Tables}

Table B.1: Market Data (January 2000)

\begin{tabular}{lcc}
\hline & SMP & Forecasted Demand \\
& $(£ /$ MWh $)$ & $(\mathrm{MW})$ \\
\hline Mean & 24.39 & $38,464.60$ \\
Min & 8.00 & $25,001.00$ \\
Max & 77.89 & $49,945.00$ \\
Std. Dev. & 12.54 & $5,247.83$ \\
\hline Frequency & $30 \mathrm{~min}$ & $30 \mathrm{~min}$ \\
Obs. & 1,488 & 1,488 \\
\hline
\end{tabular}

Source: Data set 1 described in Section 5; Authors' calculations.

Table B.2: Bid Data (January 2000)

\begin{tabular}{lcc}
\hline & $\begin{array}{c}\text { Production Capacity } \\
(\mathrm{MW})\end{array}$ & $\begin{array}{c}\text { Price Bid } \\
(£ / \mathrm{MWh})\end{array}$ \\
\hline Mean & 87.70 & 39.54 \\
Min & 0.00 & 0.00 \\
Max & 494.50 & $37,865.50$ \\
Std. Dev. & 124.06 & 106.68 \\
\hline Frequency & $30 \mathrm{~min}$ & $30 \mathrm{~min}$ \\
Obs. & 450,336 & 450,336 \\
\hline
\end{tabular}

Source: Data set 2 described in Section 5; Authors' calculations. 


\section{Abbreviations}

$\begin{array}{ll}\text { BE } & \text { British Energy } \\ \text { CC } & \text { Competition Commission (formerly, the MMC) } \\ \text { CCGT } & \text { Combined Cycle Gas Turbine } \\ \text { Ed } & \text { Edison } \\ \text { ESI } & \text { Electricity Supply Industry } \\ \text { HHI } & \text { Herfindahl-Hirschmann Index } \\ \text { LOLP } & \text { Loss of Load Probability } \\ \text { MALC } & \text { Market Abuse License Condition } \\ \text { MMC } & \text { Monopolies and Mergers Commission } \\ \text { NGC } & \text { National Grid Company } \\ \text { NP } & \text { National Power } \\ \text { OCGT } & \text { Open Cycle Gas Turbine } \\ \text { OFFER } & \text { Office of Electricity Regulation } \\ \text { OFGEM } & \text { Office of Gas and Electricity Markets (formerly, the OFFER) } \\ \text { PG } & \text { PowerGen } \\ \text { PSB } & \text { Pumped Storage Business } \\ \text { SMP } & \text { System Marginal Price }\end{array}$


Working Paper Series

ISSN 1211-3298

Registration No. (Ministry of Culture): E 19443

Individual researchers, as well as the on-line and printed versions of the CERGE-EI Working Papers (including their dissemination) were supported from the following institutional grants:

- Economic Aspects of EU and EMU Entry [Ekonomické aspekty vstupu do Evropské unie a Evropské měnové unie], No. AVOZ70850503, (2005-2011);

Specific research support and/or other grants the researchers/publications benefited from are acknowledged at the beginning of the Paper.

(c) Sherzod Tashpulatov and Lubomír Lízal, 2012

All rights reserved. No part of this publication may be reproduced, stored in a retrieval system or transmitted in any form or by any means, electronic, mechanical or photocopying, recording, or otherwise without the prior permission of the publisher.

Published by

Charles University in Prague, Center for Economic Research and Graduate Education (CERGE) and

Economics Institute ASCR, v. v. i. (EI)

CERGE-El, Politických vězňů 7, 11121 Prague 1, tel.: +420 224005 153, Czech Republic.

Printed by CERGE-EI, Prague

Subscription: CERGE-EI homepage: http://www.cerge-ei.cz

Phone: + 420224005153

Email: office@cerge-ei.cz

Web: http://www.cerge-ei.cz

Editor: Michal Kejak

Editorial board: Jan Kmenta, Randall Filer, Petr Zemčík

The paper is available online at http://www.cerge-ei.cz/publications/working_papers/.

ISBN 978-80-7343-268-3 (Univerzita Karlova. Centrum pro ekonomický výzkum a doktorské studium)

ISBN 978-80-7344-260-6 (Národohospodářský ústav AV ČR, v. v. i.) 
CERGE-EI

P.O.BOX 882

Politických vězňů 7

11121 Praha 1

Czech Republic http://www.cerge-ei.cz 